\title{
Football Club Financial Reporting: Time for a New Model?
}

\begin{tabular}{|r|l|}
\hline Journal: & Sport, Business, Management: an International Journal \\
\hline Manuscript ID: & Draft \\
\hline Manuscript Type: & Research Paper \\
\hline Keywords: & Financial fair play, financial reporting, football clubs \\
\hline \multicolumn{2}{l}{} \\
\end{tabular}

SCHOLARONE ${ }^{m}$

Manuscripts 


\title{
Football Club Financial Reporting: Time for a New Model?
}

\begin{abstract}
Purpose - To critically evaluate football club financial reporting with reference to: the long-standing debate on the nature and purpose of accounting; and the implementation of UEFA's Financial Fair Play (FFP) regulations.

Design/methodology/approach - The paper is based on a review and analysis of academic literature, accounting regulation and football regulations.

Findings - The focus of financial reporting on rational economic decision-makers results in football club financial reports being of limited use to many football club stakeholders. Consideration of the social and organisational context of football, as takes place in FFP, can be used as a catalyst to consider broader approaches to football club reporting. The paper calls for fuller and different pictures to be provided of clubs' performance, in particular broadening the scope of accountability to users beyond that provided by an economic account.

Research limitations/implications - The paper is designed to stimulate debate about accounting for and reporting on football club businesses. A necessary next step is an exploratory project, focusing on one or a small number of clubs and their stakeholders, exploring in a practical setting what enhanced football club reporting might look like.

Originality/value - While the weaknesses of financial reporting have been considered extensively in the mainstream accounting literature and on occasion in terms of sport, the paper seeks to progress this discussion by linking it to significant football policy initiatives and to wider social and community-based football research.
\end{abstract}




\section{Introduction}

The substantial increases in income enjoyed by top level football clubs in recent years coupled with the resultant benefits gained by elite players have perhaps inevitably resulted in increased emphasis on the business of football and football clubs. Financial performance has become one of the dominant narratives about football with regular commentary on financial success or failure at league and club level. More pertinently, to some extent at least, football as an economic activity has become normalised, in the sense that increasingly clubs are being viewed and reported on by leading commentators as if they were normal businesses (Moorhouse, 2007).

Notwithstanding football's highly commercialised nature, this process of normalisation is problematic: football has always been and continues to be a social business; economic in basis, but social in nature (Hamil et al., 2001; 2000, Morrow, 2003; Nash, 2000). This approach encourages recognition of the social aspects that distinguish football from purely economic activity; that is how its economic activity affects or is affected by its communities of interest or stakeholders. In recent years there has been increased attention afforded to the ways in which elite level clubs give effect to their putative social and community role and to their resultant accountability to those communities or stakeholders. At one level this has focused on the organisational and governance structure of clubs (see, for example, Frank, 2010; Hassan and Hamil, 2010; Michie and Oughton, 2005; Senaux, 2008); at another the emphasis has been on corporate social responsibility (see, for example, Breitbarth and Harris, 2008; Hamil and Morrow, 2011; Kolyperas and Sparks, 2011; Walters and Tacon, 2010).

Yet despite significant increases in income, the financial performance and position, in particular the levels of indebtedness, of many elite level clubs throughout Europe is very poor (Beech et al., 2010; Garcia and Rodriguez, 2003; Hamil and Walters, 2010; JSE, 2006; 
UEFA, 2013, 2012a, 2011, 2010). This paradoxical situation in European football finance has now directly influenced football policy, most visibly in the introduction by UEFA, European football's governing body, of Financial Fair Play (FFP) regulations as part of its Club Licensing system: explicit recognition of the weaknesses of the business model being pursued by many clubs.

The starting point for UEFA's FFP regulations are clubs' financial statements, the generally accepted means by which an organisation communicates its financial performance and position in accordance with national and international financial reporting rules and guidance. Within this context, the aim of this article is to provide a critical evaluation of conventional business financial reporting as prevailing in contemporary football clubs with a view to stimulating debate about: how we view and report on the finances of elite level football clubs; and what kind of accounting may be desirable for football clubs. While the paper concentrates on British football clubs and on the UK's financial reporting regulations, much of the paper and the discussion therein will also have relevance to other European countries. The paper is part of wider research project funded by The Institute of Chartered Accountants of Scotland's SATER Trust which, drawing on interviews with accountants with experience of football club accounting, is concerned with assessing the potential impact of FFP on football clubs and on the relationship between FFP and conventional financial reporting.

The paper is structured as follows. The paper begins with an overview of financial reporting and its objectives, providing a critique of the usefulness of financial statements to putative users of football clubs financial statements. This is followed by a consideration of the political context of financial reporting and financial reporting regulation. UEFA's FFP regulations are then discussed, introducing the notion of purpose-oriented financial reporting. In the paper's final section the possibility of broadening the types of reporting on football clubs is explored. 


\section{Financial reporting - objectives and user needs}

Accounting is the process of identifying, measuring and communicating financial information about an entity to permit informed judgement and decision making by users of that information (AAA, 1966). Financial reporting is that part of accounting which focuses on communicating with users external to the organisation and is considered to have two basic objectives: 1) accountability, i.e. that the accounts should provide information about how effectively and efficiently management has discharged its responsibilities to use and manage the entity's existing resources, sometimes referred to as control or stewardship objective; and 2) decision-making, i.e. that accounts should provide a basis for decision making (Mellemvik et al., 1988).

Financial reporting involves the preparation of general purpose financial statements in accordance with approved financial reporting standards; these statements providing information about the financial position, financial performance and cash flows of an entity, supplemented by accompanying narrative information. The primary users of general purpose financial statements are considered to be present and potential investors, lenders and other creditors, who are expected to use that information to make decisions about buying, selling or holding equity or debt instruments and providing or settling loans or other forms of credit (IFRS, 2012). What has been constructed by the financial reporting regulatory process and by standard setting bodies is hence a very specific and limited image of the financial statement user; a rational economic decision maker, concerned with economic events and transactions and with predicting their impacts upon an entity's future net cash inflows. Over the years a number of reports and frameworks have suggested that general purpose statements will also be of use to parties other than capital providers. Groups commonly identified include employees, suppliers, customers, government and the public (ASB, 1999; ASSC, 1975; ICAS, 1988; IFRS, 2012). 
In a paper written in 1986, Webb and Broadbent attempted to relate the debate on the objectives of financial statements and the identification of user needs to football clubs. They contended that the ownership structures prevalent in football clubs, in particular the concentration of control, rendered the traditional 'buy, sell, hold' decision irrelevant to most football club shareholders, arguing further that information should be provided instead on financial support required for football ambitions (Webb and Broadbent, 1986). Their work was updated by Morrow (1999) in cognisance of changes both in football and the wider regulatory environment. In this section of the paper the usefulness of football club financial statements in terms of decision making and accountability is revisited briefly for the main stakeholder groups, reflecting upon both generic issues around financial reporting and football specific issues.

\subsection{Investors}

The majority of football clubs in the UK are structured as limited liability companies, often with highly concentrated ownership structures, i.e. where one or a few individuals own a large percentage of shares (Christian Aid, 2010; Conn, 2011; Hope, 2003; Kelso, 2009; Morrow, 1999). In recent years there has been a relatively active market in clubs being bought and sold by wealthy investors / groups of investors, many of them from overseas (Christian Aid, 2010; Conn, 2011). While it is expected that prospective purchasers of clubs would have knowledge of and make use of published financial statements, as is the case in acquisitions in other sectors of the economy any purchase of a majority stake in a major football club almost inevitably would be accompanied by a process of due diligence carried out by accountants and other professionals ${ }^{1}$. In practical terms, therefore, what takes place is a private market transaction in respect of financial information, with the prospective purchaser being willing to pay for private information beyond that which is available publicly and free of charge (Wolk et al., 1992). Furthermore, out with full scale takeover or the sale of 
a controlling interest in a club, there is little evidence of an active market in the shares of football clubs, even during that period when a considerable number of British clubs were listed on the Stock Exchange (Bell et al., 2009; Morrow, 1999, 2000)². This is unsurprising: with very few exceptions (Morrow, 1999), small share holdings in football clubs have been motivated by non-financial motives, such as attachment or a sense of obligation to provide financial support to their club (de Ruyter and Wetzels, 2000; Morrow, 2000), leading to a 'buy and hold' strategy and rendering the traditional function of financial statements as informing investment decision making largely irrelevant.

Hence the financial statements' role is more obviously concerned with accountability, allowing the managers of a club to provide an account or reckoning to the shareholders for the actions for which they are held responsible. Yet, if the investment decision of supporter shareholders was not originally motivated by matters financial, it is questionable whether the demands for accountability can be met solely by financial accountability. Moreover, this emphasis fails to explore the social and organisational context in which particular types of organisation exists, something which is particularly significant for football clubs given their very distinct context (see section 3).

Returning to the issue of majority shareholders, historically their objectives tended to be characterised not in terms of profit maximisation, but rather utility maximisation, usually described in terms of maximising playing performance subject to solvency (Arnold and Beneviste, 1987; Sloane, 1971, 1980; Sutherland and Haworth, 1986). More recently as elite clubs have become increasingly dependent upon external commercial investment, some have suggested that organisational objectives have moved towards prioritising revenue generation rather than utility maximisation (Hassan and Hamil, 2010). Others argue that the contemporary football field is in fact now pluralistic with multiple actors and coexisting logics, drawing a distinction between the increased prevalence of commercial actors and the 
infrequency of conventional commercial outcomes such as profit (Gammelsæter, 2010).

Certainly maximising revenue is quite distinct from maximising profit. As is well

documented, most commonly increased revenue in top level football clubs is quickly

captured by the players in the form of increased salaries (Deloitte, 2011; Hassan and Hamil,

2010). Hence for the most part, rather than rational economic decision making what we find is economic irrationality: in pursuit of sporting success clubs compete against each other, adopting similar strategies in terms of player recruitment and retention, in the process bidding up the cost of sporting talent akin to a military arms race between nations (Dobson and Goddard, 2001; Rosen and Sanderson, 2000). As a result many clubs end up living beyond their means (Deloitte, 2012, PWC, 2012, UEFA, 2013) ${ }^{3}$.

\subsection{Lenders}

For a number of years the reported financial position of many British clubs has been very poor with numerous clubs in negative equity positions and few reporting profits and with several clubs in both England and Scotland being placed in administration (Beech et al., 2010, Buraimo et al., 2006; Morrow, 2006). Unsurprisingly over the last decade, there has been a steady decline in the number of clubs which were able to increase their bank facilities in any particular year: from over 50\% in 2002, down to just $10 \%$ in 2010 and 2011 (PKF, 2011). Banks have become reluctant lenders to the sector and resisted efforts to increase their exposure, their behaviour influenced by football specific factors like the collapse of ITV Digital and general economic factors like the global recession and banking crisis and their anticipated impact on a club's income streams and cash flow. These judgements are unlikely to be influenced by information disclosed in financial statements, instead being a function of private discussions between bankers and clubs: essentially another example of a private market in financial information (Wolk et al., 1992). In addition, historically their lending to football clubs has been influenced by non-financial factors; for example, the perceived 
importance of a football club to a local community and the bank's relationship with a club's directors (Morrow, 1997).

\subsection{Employees}

Employment structure is a distinct feature of football clubs given the importance of players. The salaries of the playing staff account for a very large percentage of the total turnover of most clubs, with an average wage to turnover ratio of $64 \%$ reported in the most recent UEFA Benchmarking Report (UEFA, 2013). Other important factors are the existence of a player transfer market and the reliance on fixed-term contracts. At the top end of football, agents play a very important role in negotiating with clubs and in seeking to maximise the economic rent and conditions in respect of their players (Roderick, 2006). At the other end of the spectrum, however, many players are not in a position to determine their future, with the balance of power in any contract or transfer negotiations remaining firmly with a club's directors: in Magee's terms, these are 'the exploited' (Magee, 1998 cited in Roderick, 2006) ${ }^{4}$. However, wherever players lie on the power spectrum, it is difficult to imagine that in conducting their contractual negotiations players or their agents make great use of a club's financial statements. At one end of the spectrum again there will be some form or private negotiation, focusing where possible on ensuring that a player is rewarded at the market rate; at the other, passive acceptance or otherwise of a club's offer. Ability to pay becomes real in its consequences only when a club has demonstrable cash flow problems and/or is placed in administration.

\subsection{Supporters}

The peculiar combination of increased revenue generation and on-going weaknesses in clubs' financial management has led to increased demand from clubs' supporters for accountability. While decision makers in clubs and the popular press understand this desire and are in a position to profit from supporters' attachments to their clubs, the nature of the field within 
which clubs play means that genuine accountability is not easily achieved by supporters (Cooper and Johnston, 2012). At one level financial statements are likely to be a useful source of information to some supporters in terms of accountability. However, their potential usefulness is limited by generic criticisms of financial reports, most notably their lack of timeliness which results in historical accountability, and their focus only on those things that are deemed important by the pervasive neo classical economic model. Hence while the financial statements present a narrative of financial performance, broader areas of legitimate interest which lie at the heart of some supporters' relationship with their clubs such as community and social engagement - activities which are also likely to be of interest to community groups and to facets of government - are ignored or peripheral to the disclosure. For example, while many clubs engage extensively in corporate social responsibility, the value or significance of this is often under-reported in the annual report (Hamil and Morrow, 2011). In addition, it is also the case that supporters are not seen as primary recipients of football clubs' financial statements: while some clubs do make their annual reports available on club websites, others do not, forcing interested parties to have to acquire the statements from Companies House.

\subsection{Governing bodies}

The nature of football regulation means that governing bodies and leagues already have an interest in their clubs' financial reporting. While the UK does not operate as demanding a licensing system as found in several other European countries like France, the Netherlands or Germany (see, for example, Pieters and De Schryver, 2011; Senaux, 2011; Wilkesmann et al., 2011), nevertheless as part of the national licensing system, clubs in Scotland are obliged to provide copies of their audited annual financial statements to the SFA (SFA, 2013, Criteria 8.11), while in England, for example, Premier League rules now require clubs to provide a limited amount of future financial information, in addition to accounts for the most recent 
period (The Football Association Premier League, 2012, E.3,11,12). UEFA’s growing interest in financial regulation is considered in section 4.

\section{The political context of accounting}

The International Financial Reporting Standards (IFRS) framework makes it clear that to be useful, financial information must be relevant and that it must also represent faithfully the phenomena it purports to represent; this relying on underlying characteristics of completeness, neutrality and freedom from error (IFRS, 2012). However, while in principle accounting provides a politically neutral set of social technologies with which to regulate business activity, the application of those technologies is inevitably political and is fashioned by the institutional and cultural setting in which the regulation takes place (Moran, 2010). To many financial reporting is not and cannot simply be a technical process (Hopwood, 2000; 1992; Miller, 1994; Potter, 2005): it has an unambiguous political and social dimension in terms of what is reported and according to which rules, and also in terms of how people respond to those numbers. Hence, in order to develop a broader understanding of accounting and the central role it plays in society, we need to consider it from a social perspective, considering the relationships between financial reporting and wider institutional and social structures (Hopwood, 2000).

European football takes place in a very specific institutional, social and political setting. It is heavily regulated by transnational governing bodies like and UEFA and also FIFA, as well as national ones; regulation focusing on matters as wide ranging as the rules of the game, anti-doping, club licensing and now Financial Fair Play. It is also not uncommon for national and transnational governments and politicians to involve themselves in aspects of football's governance (e.g. Culture, Media and Sport Committee Inquiry, 2011; DCMS, 2012); the level of political interest being largely unrelated to football's financial significance. Moreover, a 
number of factors distinguish football clubs from conventional companies: the nature and importance of relationships between stakeholders and their clubs (Brown et al., 2006; Brown et al., 2008; Morrow, 1999, 2003); customer loyalty or partisanship (Simmons, 2006); high levels of stakeholder engagement and activism (Michie and Oughton, 2005; Morrow, 1999); and the enduring relationships between clubs and geographical communities (Bale, 2002; Brown et al,. 2008). Given this, interest in accounting as a social and institutional practice rather than merely a technical practice and in research that probes the applications of accounting in specific social and organisational contexts is potentially of great relevance to organisations like football clubs (Potter, 2005). This perspective of accounting places emphasis on the relationship between what we measure, how we measure it and why we measure it, and on different approaches to managing organisations and societies. McKernan (2007) suggests that the active exploration and development of socio-political justifications for accounting practices may enable more focus on its real practical contributions rather than its scientific credentials. With this in mind, attention is now turned UEFA's FFP regulations and a consideration of whether they provide an opportunity for a context-specific approach to football club financial reporting.

\section{Financial Fair Play Regulations}

UEFA's response to the financial situation that many European clubs find themselves in has been to introduce FFP Regulations, as it seeks to protect the integrity and smooth running of its club competitions ((UEFA, 2012b, Article 2, Para. 1(d)). Over a period of time those clubs which wish to participate in its Europe-wide club competitions are encouraged through the regulations to adopt a more economically rational approach to their activities.

The aim is to achieve FFP in UEFA club competitions, in particular to: 
- improve economic and financial capability of clubs, increasing their transparency and credibility;

- place the necessary importance on the protection of creditors and to ensure that clubs settle their liabilities with players, social / taxation authorities and other clubs punctually;

- introduce more discipline and rationality in club football finances;

- encourage clubs to operate on the basis of their own revenues;

- encourage responsible spending for the long-term benefit of football;

- protect the long-term viability and sustainability of European club football (UEFA, 2012b, Article 2, Para 2).

While FFP is clearly about encouraging financial rationality, importantly the regulations are reflective of the specific sporting and social context in which football clubs exist, and draw attention to accounting as a social and institutional practice rather than merely a technical practice (Potter, 2005). There is explicit recognition of the inter-dependence of clubs which participate in particular leagues and competitions and of the accountability of one club to another, and of the consequences of this interdependence for the integrity of these competitions. In accounting language FFP is designed to ensure that football is a going concern, in other words to safeguard the continuity of international competition in any one season. The key performance measure in the regulations is the break even requirement; specifically that over a three year rolling period (beginning with the financial year 2011/12) clubs should break even subject to a defined level of acceptable deviation (UEFA, 2012, Article 61). Break-even is determined by comparing relevant income with relevant income (see Figure 1). 
[insert Figure 1 here]

That expenditure on community development activities need not be included as a relevant cost in determining break-even is an acknowledgement that these are not normal businesses, but instead organisations which are accountable to and which have obligation to the communities from which they derived in the first instance. Under FFP such expenditure is not seen as discretionary business expenditure but rather as an investment necessary to maintain a club's relationship with its communities. At the same time, however, while the FFP break even calculative approach throws light on a broader conceptualisation of organisational behaviour and performance, as things stand it has not actually improved accountability as such information remains largely hidden from the view of most stakeholders.

The exclusion of finance costs incurred in constructing tangible fixed assets is also of interest. In effect what this does is to introduce a distinction between good debt and bad debt, where debt taken on in respect of developing say a new stadium or training academy is considered good, while debt taken on say to purchase new players or meet players' salary obligations is considered bad. This distinction is entirely consistent with UEFA's aim of encouraging responsible spending for the long term benefit of football. But it is important to recognise that this is a political or value judgement by UEFA based upon improving the overall social welfare of football, rather than on what may be in the best interests of individual football clubs or particular stakeholders of those clubs (Cooper and Sherer, 1984). Hence FFP can be characterised as a form of normative regulation.

The requirement for modified financial information is a clear demonstration that general purpose financial statements, primarily targeted at investors and lenders, do not meet UEFA's needs in terms of its social and sporting purpose. In contrast to conventional financial statements which emphasise financial performance at the level of a club, focused on a narrow 
group of economically motivated users, FFP is about prioritising social and sporting public policy objectives at the level of the competition. Thus FFP can be interpreted as contributing to shaping a social (sporting) reality with beneficial social outcomes - the accounting numbers required by UEFA and the value judgements made are political in that they have been selected with a particular outcome in mind. Essentially UEFA has put forward a public interest argument for regulation, i.e. the long run integrity of its competitions is asserted to be for the greater good of football and hence of society. Moreover, FFP has social and political consequences in terms of whether clubs will be licenced to participate in UEFA's competitions. From the clubs' perspective, FFP and the accounting process provides an opportunity for them to legitimate themselves and to obtain (financial) resources from their environment, through participation in UEFA's financially lucrative competitions.

\section{FFP - implications for football club reporting}

As the business side of football has grown there is evidence that clubs have sought to increase the quantity of information that they disclose to interested stakeholders, with longer reports and increased emphasis on free-form business narrative (Morrow, 2005). In recent years there is also evidence of increased voluntary social disclosure in annual reports, as well as in other sources like websites (Hamil and Morrow, 2011; Slack and Shrives, 2008; Walters and Tacon, 2010), with clubs seeking to provide a fuller picture of their performance than simply a financial one. As organisations which have their origins in communities at one level it is unsurprising that football clubs may seek to be accountable to the communities from which they initially derived (Slack and Shrives, 2008; Morrow, 1999; Brown et al., 2006).

However, while the desire to disclose more information is broadly welcome, a number of issues arise. Firstly, as social disclosure is less standardised than conventional financial disclosure, there is a risk of management capture, with management seeking to control the debate about what is or is not appropriate social or community activity, both in terms of 
engagement and disclosure (O’Dwyer, 2004). Hence, the social disclosure can be more about public relations or impression management than accountability (Hooghiemstra, 2000; L'Etang, 1994). Increased narrative disclosure may also be motivated by legitimacy concerns. Slack and Shrives (2008) suggest that increased social disclosure is a sector wide response to questions about its legitimacy, including concerns rising from the commercialisation of the game such as player wage levels, but also broader social and ethical concerns such as the environmental impact of facility development, racism and hooliganism.

Hence, while a fuller picture can be provided, it may remain a very partial picture. One of the challenges that accounting faces is that what is accounted for shapes views of what is important (Burchell et al., 1980). Moreover, as discussed in terms of FFP and good debt / bad debt, the things that accountants account for or report on are not naturally determined but reflect value judgements about to whom and for what an entity is responsible. Over the last couple of decades there has been increased interest in accountants seeking to broaden the scope of accounts beyond something that is exclusively economic in content, searching for ways in which organisations can be held accountable for a broader range of activities and to a broader range of actors (Arrington and Francis, 1993). There now exists a substantial body of literature around what is termed social accounting, where externally produced accounts of institutional activity or intentions are produced and which seek to discharge an organisation's accountability to its stakeholders. These include terms like silent accounts, social accounts and shadow accounts; key to which are the need to engage non-managerial stakeholder voices. Typically these accounts will be prepared by, or on behalf of, less powerful social groups and/or the environment and therefore may be thought of as an 'accounting for the other, by the other' to justify some form of corrective action (Shearer, 2002). Less emphasis is placed on calculative rationality in social reports, i.e. the reports contain not only statistical 
and financial information but also narrative which account for social and environmental impacts (Spence, 2007; Spence and Thomson, 2009).

These broader perspectives on accountability are potentially significant in terms of FFP given that it is predicated on an understanding of the distinct nature of football, its clubs, and of competition. Hence FFP illuminates football as an appropriate site to investigate how best to provide an alternative understanding of clubs' performance and contribution, financial and social: in effect widening the number of 'stories' told about them; focusing on different ways of seeing and of different things to see (Hines, 1988). In organisations like football clubs the health of relationships between the club and its stakeholders like supporters, its employees and its communities (however defined) could be seen as equally important as cash flows, profits and debt levels. Moreover there is evidence of legitimate and on-going interest in the activities of these institutions from various parts of government, the public sector and the third sector. A broader conception of reporting may enable clubs to present a more positive picture of their societal role than is currently the case. This approach is also consistent with argument that in order not to lose sight of their true purpose, not-for-profit organisations which in practice is what most football clubs are despite their corporate structure (Gammelsæter, 2010) - ought to have management and reporting structures that deal with multiple bottom lines and which emphasise a holistic conception of the organisation (Anheier, 2005).

It is widely accepted that most football clubs, irrespective of their organisational structure, have highly engaged supporters, as well as often other stakeholder groups. Thus it can be argued that football has what Feldman (2000) calls 'already willing listeners'; those who wish to 'participate, to be changed, or at least to acquiesce to the telling [of the story]'. The engagement of key stakeholders may also provide an opportunity to consider ever more innovative forms of reporting and accountability. For example, drawing on work that seeks to 
promote customer self-accounting using information technology and new media (Roslender and Hart, 2010), perhaps an opportunity exists to facilitate supporters and others to provide an autonomous complementary narrative, allowing progressive clubs to provide evidence of mutually reinforcing stories?

Some football specific work on the social and community value and role of football has been carried out already by Brown et al. (2010), its aims including investigating ways in which to measure or account for the social and community value of football clubs and outlining how the community role of football clubs relates to wider regulatory issues. Alongside the final report, a number of working papers were produced which sought to provide a broader framework within which to consider the social and community value of football by relating it to wider debate around areas like social accounting (Ashton, 2008), social value (New Economics Foundation (2008), the valuation of public goods (Barlow, 2008), and measuring the social impact of football (Casey-Challies, 2008). The report concluded that football as a whole has a great deal to gain from promoting an improved understanding of its social value, of developing an appropriate framework through which it can be assessed and of reporting its activities. In terms of motivations, it observed that 'there are good business reasons as well as those of an enlightened self-interest in taking [the promotion and reporting of the social value of football] more seriously' (Brown et al., 2010, 56). While this report's specific focus was on how best to measure and report the social value and contribution made by football clubs, the approaches used therein complement proposals made in this paper for the approach and principles underlying FFP to catalyse consideration of broader forms of football club reporting.

\section{Conclusion}

Presently football club financial reports are in substance no different from those produced for organisations in other areas of business activity. As a result the focus is on providing useful 
information to rational economic decision makers, that information concentrating on economic events and transactions and their predicted financial impacts. However, the nature of football clubs and the behaviour of many of their stakeholders, more often than not including their shareholders, leave these financial reports ill-suited to meet the perceived objectives and needs of stakeholders.

UEFA's FFP regulations demonstrate that while financial reporting information remains fundamentally important in terms of financial accountability and assurance, to make the information useful it requires to be prepared, or in this case arranged, with a particular purpose in mind and with due attention to social and organisational context. That context, and in particular the depiction of football clubs as being, at least in some sense, social and community institutions, also encourages consideration of the merits of providing fuller and different pictures of the performance of clubs. One benefit of so doing is that it broadens the scope of accountability demanded of clubs beyond merely economic or financial accounts. In addition, given the engaged nature of many football club stakeholders it may also provide an opportunity for other voices to contribute to football club reporting. To progress this discussion further, what is now required is an exploratory project, focusing on one or a small number of clubs and their stakeholders, the purpose of which is to explore in a practical setting what could an enhanced football club report might look like.

\section{References}

AAA (1966), A Statement of Basic Accounting Theory, American Accounting Association: Evanston, Illinois.

Anheier, H.K. (2005), Nonprofit Organizations: Theory, Management and Policy, Routledge, London. 
Arnold, A. and Beneviste, I. (1987), "Wealth and poverty in the English Football League", Accounting and Business Research, Vol. 17, No. 67, pp. 195-203.

Arrington, C.E. and Francis, J.R. (1993), "Giving economic accounts: accounting as a cultural practice”, Accounting, Organizations and Society, Vol. 17, No. 4, pp. 107-124.

ASB (1999), Statement of Principles, Accounting Standards Board, London.

Ashton, A. (2008), Playing with a standard formation: social accounting for football clubs and supporters trusts - towards a unified approach, Substance, Manchester.

ASSC (1975), The Corporate Report. The Accounting Standards Steering Committee, London.

Bale, J. (2002), Sport, Space and the City, The Blackburn Press, London.

Barlow, A. (2008), Do we know the true value of football? A review of the methodologies used to value public goods, Substance, Manchester.

Beech, J., Horsman, S. and Magraw, J. (2010), “Insolvency events among English football clubs", International Journal of Sports Marketing \& Sponsorship, Vol. 11, No. 3, pp. 236249.

Bell, A., Brooks, C., Matthews D. and Sutcliffe, C. (2009), “Over the moon or sick as a parrot? The effects of football results on a club's share price", ICMA Discussion Papers in Finance DP2009-08.

Benkraiem, R., Louhichi, W. and Marques, P. (2009), "Market reaction to sporting results: The case of European listed football clubs", Management Decision, Vol. 47, No. 1, pp. 100109. 
Breitbarth, T. and Harris, P. (2008), “The role of corporate social responsibility in the football business: Towards the development of a conceptual model", European Sport Management Quarterly, Vol. 8, No. 2, pp. 179-216.

Brown, A, Crabbe, T. and Mellor, G. (2008), Football and Community in a Global Context: Studies in Theory and Practice, Routledge, London.

Brown, A., Crabbe, T., Mellor, G., Blackshaw T. and Stone, C. (2006), Football and its Communities: Final Report, Football Foundation, London.

Brown, A., McGee, F. Brown, M. and Ashton, A. (2010), The Social and Community Value of Football. The Final Report, Supporters Direct, London.

Buraimo, B., Simmons, R. and Szymanski, S. (2006), "English football”, Journal of Sports Economics, Vol. 7, No. 1, pp. 29-46.

Burchell, S., Clubb, C., Hopwood, A., Hughes, J. and Nahapiet, J. (1980), “The roles of accounting in organizations and society", Accounting, Organizations and Society, Vol. 5, No. 1, pp. 5-27.

Casey-Challies, R. (2008), Measuring the Social Impact of Football, Substance, Manchester. Christian Aid (2010), Blowing the Whistle: Time's Up for Financial Secrecy. A Christian Aid Report, May.

Conn, D. (2011), "Record income but record losses for Premier League”, The Guardian, 19 May.

Conn, D. (2013), “Swansea’s halo slips after owners decide to pocket $£ 2 \mathrm{~m}$ windfall’, The Guardian, 9 April, p. 48. 
Cooper, C. and Johnston, J. (2012), "Vulgate accountability - insights from the world of football”, Accounting, Auditing \& Accountability Journal, Vol. 25, No. 4, pp. 602-634.

Cooper, D.J. and Sherer, M.J. (1984), “The value of corporate accounting reports: Arguments for a political economy of accounting", Accounting, Organizations and Society, Vol. 9, No. 3/4, pp. 207-232.

Culture, Media and Sport Committee Inquiry (2011), Football Governance (HC792-1).

DCMS (2012), Football Governance: Response to the Culture, Media and Sport Committee Inquiry (HC792-1).

Deloitte, 2012, New Rules, Narrow Margins: Annual Review of Football Finance 2012, Deloitte, Manchester.

Deloitte, 2011, Pressure to Change: Annual Review of Football Finance 2011, Deloitte, Manchester.

de Ruyter, K. and Wetzels, M. (2000), "With a little help from my friends - Extending models of pro social behaviour to explain supporters' intentions to buy soccer club shares", Journal of Economic Psychology, Vol. 21, pp. 387-409.

Dobson, S. and Goddard, J. (2001), The Economics of Football. Cambridge University Press, Cambridge.

Feldman, A. (2000), “Othering knowledge and unknowing law: oppositional narratives in struggle for American Indian religious freedom”, Social \& Legal Studies, Vol. 9, No. 4, pp. $557-82$.

The Football Association Premier League (2012), Premier League Handbook Season 2012/13, FAPL, London. 
Frank, E. (2010), 'Private firm, public company or members' association? Governance and structure in European football”, International Journal of Sport Finance, Vol. 5, No. 2, pp. 108-127.

Gammelsæter, H. (2010), “Institutional pluralism and governance in 'commercialized' sport clubs", European Sport Management Quarterly, Vol. 10, No. 5, pp. 569-594.

Garcia, J. and Rodriguez, P. (2003), "From sports clubs to stock companies: The financial structure of football in Spain, 1992-2001”, European Sport Management Quarterly, Vol. 3, No. 3, pp. 253-269.

Hamil, S. and Morrow, S. (2011), "Corporate social responsibility in the Scottish Premier League: Context and motivation", European Sport Management Quarterly, Vol. 11, No. 2, pp. 143-170.

Hamil, S. and Walters, G. (2010), "Financial performance in English professional football: ‘An Inconvenient Truth’”, Soccer \& Society, Vol. 11, No. 4, pp. 354-372

Hamil, S., Michie, J., Oughton, C. and Warby, S. (eds) (2001), The Changing Face of the Football Business: Supporters Direct, Frank Cass, London.

Hamil, S., Michie, J., Oughton, C. and Warby, S. (eds) (2000), Football in the Digital Age: Whose Game is it Anyway? Mainstream, Edinburgh.

Hassan, D. and Hamil, S. (eds) (2010), Who Owns the Game? Football Governance in the Twenty First Century, Routledge, London.

Hines, R. (1988), "Financial accounting: In communicating reality, we construct reality". Accounting, Organisations and Society, Vol. 13, No. 3, pp. 251 - 261. 
Hooghiemstra, R. (2000), “Corporate communication and impression management - new perspective why companies engage in corporate social reporting", Journal of Business Ethics, Vol. 27, No. 1/2, pp. 55-68.

Hope, S. (2003), “The ownership structure of Nationwide League football clubs 2002-03”, Football Governance Research Centre Research Paper No. 5, FGRC, London.

Hopwood, A.G. (2000), "Understanding financial accounting practice”, Accounting, Organizations and Society, Vol. 25, No. 8, pp. 763-766.

Hopwood, A. (1992), "Accounting calculation and the shifting sphere of the economic", European Accounting Review, Vol. 1, No. 1, pp. 125-143.

ICAS (1988), Making Corporate Reports Valuable, Institute of Chartered Accountants of Scotland, Edinburgh.

IFRS (2012), The Conceptual Framework for Financial Reporting 2011.

JSE (2006), Journal of Sports Economics, Special issue on the crises in European football, Vol. 7, No. 1.

Kelso, P. (2009), "So who really owns England's top clubs? We're waiting to find out", The Daily Telegraph, 2 September.

Kolyperas, D. and Sparks, D. (2011), “Corporate social responsibility (CSR) communications in the G-25 football clubs", International Journal of Sport Management and Marketing, Vol. 10, No. $1 / 2$, pp. $83-103$

L'Etang, J. (1994), "Public relations and corporate social responsibility: Some issues arising" Journal of Business Ethics, Vol. 13, No. 2, pp. 111-123. 
McCarthy, D. (2011), "Football finance expert admits Rangers takeover is dragging on longer than most would expect", The Daily Record, April 8.

McKernan, J.F. (2007), "Objectivity in accounting”, Accounting, Organizations and Society, Vol. 32, No. 1/2, pp. 155-180.

Magee, J.D. (1998), International labour migration in English league football. Unpublished $\mathrm{PhD}$ thesis.

Mellemvik, F., Monsen, N. and Olsen, O. (1988), "Functions of accounting: A discussion", Scandinavian Journal of Management, Vol. 4, No. 3/4, pp. 101-199.

Michie, J. and Oughton, C. (2005), “The corporate governance of professional football clubs in England”, Corporate Governance: An International Review, Vol. 13, No. 4, pp. 517-531.

Miller, P. (1994), “Accounting as Social and Institutional Practice: An Introduction”, in Hopwood, A. and Miller, P. (Eds), Accounting as Social and Institutional Practice, Cambridge University Press, Cambridge, pp.1-39.

Moorhouse, H.F. (2007), "Financial expertise, authority and power in the European football ‘industry”, Journal of Contemporary European Research, Vol. 3, No. 3, pp. 290-299.

Moran, M. (2010), “The political economy of regulation: Does it have any lessons for accounting research?", Accounting and Business Research, Vol. 40, No. 3, pp. 215-225.

Morrow, S. (2006), "Scottish football: It's a funny old business", Journal of Sports Economics, Vol. 7, No. 1, pp. 90-95.

Morrow, S. (2005), The Business of Football: Image Management in Narrative Communication, Institute of Chartered Accountants of Scotland, Edinburgh. 
Morrow, S. (2003), The People's Game? Football, Finance and Society, Palgrave, Basingstoke.

Morrow, S. (2000), "Football clubs on the Stock Exchange: an inappropriate match?”, The Irish Accounting Review, Vol. 7, No. 2, pp. 61-90.

Morrow, S. (1999), The New Business of Football. Accountability and Finance in Football, Macmillan, Basingstoke.

Morrow, S. (1997), “Accounting for football players. Financial and accounting implications of 'Royal Club Liegois and others versus Bosman' for football in the United Kingdom”, Journal of Human Resource Costing and Accounting, Vol. 2, No. 1, pp. 55-71.

Nash, R. (2000), “The sociology of English football”, Football Studies, Vol. 3, No. 1, pp. 4962.

New Economics Foundation, (2008), Football, Ownership and Social Value, Substance, Manchester.

O’Dwyer, B. (2004), “Stakeholder democracy: Challenges and contributions from accountancy”, ICCST research Paper No. 18-2004, Nottingham: International Centre for Corporate Social Responsibility.

Pieters, M. and De Schryver, T. (2011), "When stoplights stay orange: Control issues in Dutch football”, in Gammelsæter, H. and Senaux, B. (Eds), The Organisation and Governance of Top Football across Europe: An Institutional Perspective, Routledge:

Abingdon, pp. 154-167.

PKF (2011), Open to Attack: The Annual Survey of Football Club Finance Directors 2011, PKF, London. 
Potter, B.N. (2005), “Accounting as a social and institutional practice: Perspectives to enrich our understanding of accounting changes", Abacus, Vol. 41, No. 3, pp. 265-289.

PWC (2012), Pricewaterhouse Coopers $23^{\text {rd }}$ Annual Financial Review of Scottish Premier League Football season 2010-11, PWC, Glasgow.

Roderick, M. (2006), The Work of Professional Football: A Labour of Love? Routledge, Abingdon.

Rosen, S. and Sanderson, A. (2000), “Labour Markets in professional team sports”, National Bureau of Economic Research Working Paper, 7573, National Bureau of Economic Research, Cambridge, Mass.

Roslender, R. and Hart, S.J. (2010), "Taking the customer into account: transcending the construction of the customer through the self-promotion of self-accounting", Critical Perspectives on Accounting, Vol. 21, No. 8, pp. 739-753.

Senaux, B. (2011), “The regulated commercialisation of French football”, in Gammelsæter, H. and Senaux, B. (Eds), The Organisation and Governance of Top Football across Europe: An Institutional Perspective, Routledge: Abingdon, pp. 123-137.

Senaux, B. (2008), “A stakeholder-approach to football club governance”, International Journal of Sport Management and Marketing, Vol. 4, No. 1, pp. 4-17.

SFA (2013), National Club Licensing, Scottish Football Association, Glasgow.

Shearer, T. (2002), "Ethics and accountability: from the for-itself to the for-the-other", Accounting, Organizations and Society, Vol. 27, No. 6, pp. 541-573.

Simmons, R. (2006), “The demand for spectator sports”, in Andreff, W. and Szymanski, S. (Eds), Handbook on the Economics of Sports, Edward Elgar: Cheltenham, pp. 77-89. 
Slack, R. and Shrives, P. (2008), "Social disclosure and legitimacy in Premier League football clubs: the first ten years", Journal of Applied Accounting Research, Vol. 9, No. 1, pp.17-28.

Sloane, P. (1980), Sport in the Market, Hobart Paper 85, The Institute of Economic Affairs, London.

Sloane, P. (1971), "The economics of professional football: the football club as a utility maximiser", Scottish Journal of Political Economy, Vol. 17, No. 2, pp. 121-146.

Spence, C. (2007), "Social and environmental reporting and hegemonic discourse", Accounting, Auditing \& Accountability Journal, Vol. 20, No. 6, pp. 855-882.

Spence, C. and Thomson, I. (2009), "Resonance tropes in corporate philanthropy discourses", Business Ethics: A European Review, Vol. 18, No. 4, pp. 372-388.

Sutherland, R.J. and Haworth, M. (1986), “The economics of the industry”, Managerial Finance, Vol. 12, No. 1, pp. 25-29.

UEFA (2013), The European Club Footballing Landscape: Club Licensing Benchmarking Report Financial Year 2011, UEFA, Nyon.

UEFA (2012a), The European Club Footballing Landscape: Club Licensing Benchmarking Report Financial Year 2010, UEFA, Nyon.

UEFA (2012b), Financial fair play and club licensing regulations, Edition 2012, UEFA, Nyon.

UEFA (2011), The European Club Footballing Landscape: Club Licensing Benchmarking Report Financial Year 2009, UEFA, Nyon. 
UEFA (2010), The European Club Footballing Landscape: Club Licensing Benchmarking Report Financial Year 2008, UEFA, Nyon.

UEFA, EPFL, ECA and FIFPro Division Europe (2012), Agreement regarding the minimum requirements for standard player contracts in the professional football sector in the European Union, and in the rest of the UEFA territory, Compromise proposal HW $24 / 01 / 2011$.

Walters, G and Tacon, R. (2010), “Corporate social responsibility in sport: Stakeholder management in the UK football industry, Journal of Management and Organization, Vol. 16, No. 4, pp. 566-586.

Webb, B.J. and Broadbent, J.M. (1986), "Finance and football clubs: What cash flow analysis reveals", Managerial Finance, Vol. 12, No. 11, pp. 6-10.

Wilkesmann, U., Blutner, D. and Müller, C. (2011), “German football: Organising for the European top", in Gammelsæter, H. and Senaux, B. (Eds), The Organisation and Governance of Top Football across Europe: An Institutional Perspective, Routledge: Abingdon, pp. 138153.

Wolk, H., Francis, J.R. and Tierney, M.G. (1992), Accounting Theory: A conceptual and institutional approach, South-Western Publishing Co., Cincinnati, Ohio.

\footnotetext{
${ }^{1}$ For example, one of the leading multinational accounting firms, Ernst \& Young, were involved in the takeovers at Chelsea, Liverpool and Manchester City (McCarthy, 2011).

${ }^{2}$ In a study of share price movements of listed European football clubs, Benkraiem et al. (2009), did find evidence of abnormal trading volume around sporting results (win, lose or draw), but no details were provided in the paper as to the absolute volumes found.

${ }^{3}$ Exceptions do exist. For example, Premier League club Swansea City aims to make a profit, recently announcing a dividend to be paid to its owners, including the Swansea City Supporters' Trust (Conn, 2013).
} 
2

\footnotetext{
${ }^{4}$ In April 2012, however, an agreement was signed between FIFPro, UEFA, ECA (European Club Association) and EPL (European Premier Leagues), ensuring that player contacts throughout Europe meet certain minimum standards (UEFA, EPFL, ECA and FIFPro Division Europe, 2012).
} 
Figure 1: The Break-Even Requirement

The difference between relevant income and relevant expenses is the break even result.

The aggregate break-even result is the sum of the break-even results of each accounting period covered by the monitoring period.

Relevant income and relevant expenses are defined in Article 58, paragraphs 1 and 2.

Relevant expenses does not include 'depreciation/impairment of tangible fixed assets, amortisation/impairment of intangible fixed assets (other than player registrations), expenditure on youth development activities, expenditure on community development activities, any other non-monetary items, finance costs directly attributable to the construction of tangible fixed assets, tax expenses or certain expenses from non-football operations' (Article 58, para 2).

Source: UEFA Club Licensing and Fair Play Regulations Edition 2012 (UEFA, 2012b) 